\title{
OsIQD14 regulates rice grain shape through modulating the microtubule cytoskeleton
}

Baojun Yang ${ }^{1,3,4}$, Jos R. Wendrich ${ }^{2,3,4}$, Bert De Rybel ${ }^{2,3,4}$, Dolf Weijers ${ }^{2 *}$ and Hongwei Xue ${ }^{1 *}$

1 National Key Laboratory of Plant Molecular Genetics, CAS Center for Excellence in Molecular Plant Sciences, Shanghai Institute of Plant Physiology and Ecology, Chinese Academy of Sciences, 300 Fenglin Road, 200032 Shanghai, China

${ }^{2}$ Laboratory of Biochemistry, Wageningen University, Stippeneng 4, 6708 WE Wageningen The Netherlands.

${ }^{3}$ Ghent University, Department of Plant Biotechnology and Bioinformatics, 9052 Ghent, Belgium

${ }^{4}$ VIB Center for Plant Systems Biology, 9052 Ghent, Belgium

Key words: OsIQD14, CaM, SPR2, microtubule, cell shape, rice, seed

*Corresponding author. E-mail:

Hongwei Xue: hwxue@sibs.ac.cn

DolfWeijers: dolf.weijers@wur.nl 
Cortical microtubule (MT) arrays play a critical role in plant cell shape determination by defining the direction of cell expansion ${ }^{1-3}$. The control of plant organ shape and architecture is a major target of cereal crop improvement. Given the pleiotropic effects of MT modification, however, it is challenging to exploiting MT array organization for crop improvement. Moreover, as plants continuously adapt cell growth and expansion to ever-changing environmental conditions, multiple environmental (e.g. light ${ }^{4}$ ) and developmental (e.g. hormones ${ }^{5,6}$ ) inputs need to be translated into changes of the MT cytoskeleton. Here, we identify and functionally characterize an auxin-inducible and MT-localized protein OsIQ67-DOMAIN14 (OsIQD14), which is highly expressed in rice seed hull cells. While deficiency of $O$ sIQD14 results in short and wide seeds and increases overall yield, overexpression leads to narrow and long seeds, caused by changes in the direction of MT arrangement. We further show that OsIQD14-mediated MT reordering is regulated through interacting with SPIRAL2, a MT-binding protein involved in KATANIN1-mediated MT rearrangement ${ }^{7,8}$, and with calmodulin proteins. As such, OsIQD14 acts as an integrator of auxin and calcium inputs into MT rearrangements, and allows effective local cell shape manipulation to improve a key rice yield trait.

The IQ67 domain (IQD) protein family contains a conserved 67 amino acid domain, and was first identified in Arabidopsis, where it is represented by a gene family with 33 members ${ }^{9}$. Several IQD proteins have been shown to interact with Calmodulin through their IQ67 domain ${ }^{10-12}$. However, the biological relevance of this interaction and the function of IQD proteins remains largely unknown. The AtIQD15-18 subclade was suggested to act downstream of the AUXIN RESPONSE FACTOR5/MONOPTEROS (ARF5/MP) transcription factor ${ }^{13}$. Rice shares OsIQD14 as a single ortholog to the AtIQD15-18 subclade (Wendrich et al, submitted ${ }^{14}$ ). To investigate the role of OsIQD14, we first analyzed its expression pattern using the transcript digital gene chip and found it to be highly expressed in inflorescences, pistils, and spikelet hull tissues (Supplemental Fig. 1a-b). Quantitative RTPCR (qRT-PCR) analysis showed that $O s I Q D 14$ transcripts can be detected during panicle development, peaking around the middle stage and gradually decreasing in mature stages of development (Supplemental Fig. 1c). We further analyzed the expression pattern by fusing the OsIQD14 promoter region to the ß-glucuronidase (GUS) reporter. Young spikelet hulls and anthers showed a strong GUS signal (Fig. 1a-c), indicating that OsIQD14 may play a role during rice spikelet hull development. Because members of the AtIQD15-18 subclade act 
downstream of $\mathrm{MP}^{13}$ and are auxin-inducible (Wendrich et al, submitted ${ }^{14}$ ); we analyzed OsIQD14 transcript levels upon exogenous auxin treatment. qRT-PCR analysis confirmed that OsIQD14 transcripts were quickly induced upon auxin (Indole 3-Acetic Acid) treatment (Fig. 1d). Moreover, the rice ortholog of AtMP, OsARF11, is transcribed throughout the panicle development similar to OsIQD14 (Supplemental Fig. 1d), suggesting that the auxin-inducible OsIQD14 transcripts could be under the control of OsARF11.

To define the biological function of $O S I Q D 14$, we generated loss-of-function mutants by using CRISPR/Cas9 technology ${ }^{15}$. Construct expressing a guide RNA targeting the first exon of OsIQD14 was transformed into ZH11 wild type rice plants. Four independent homozygous lines were isolated that carried frame shift mutations resulting from a 1-bp insertion or a 5-bp, 22-bp or 34-bp deletion, respectively (Supplemental Fig. 2a). None of the independent mutants presented a visible phenotype during vegetative growth, but all produced wider and shorter grains compared to those of ZH11 (Fig. 1e-f, h-i and Supplemental Fig. 2b), demonstrating a role for OsIQD14 in panicle and spikelet development. For all further analyses, the 5-bp deletion iqd14-c mutant was selected. Next, we generated overexpression plants by driving OsIQD14 from the strong p35S promoter in a ZH11 background (p35S::OsIQD14 or OsIQD14-OE). In contrast to the ZH11 and iqd14-c mutant, OsIQD14-OE plants produced narrower and longer grains (Fig. 1g, j and k-1). Furthermore, the 1000-grain weight of iqd14$c$ was significantly increased compared to that of ZH11, while that of OSIQD14-OE was similar to ZH11 (Fig. 1m). Importantly, the panicle of iqd14-c and IQD14-OE was similar to that of ZH11 (Fig. 1n). As the spikelet hull has been proposed to restrict growth of a grain and as such determines the grain size of rice, we examined cell morphology in the outer glume of the lemma of ZH11, iqd14-c and IQD14-OE plants. Scanning electron microscopy (SEM) analysis revealed that iqd14-c spikelet hull cells were shorter and wider than that of ZH11. Conversely, the hull cells of IQD14-OE plants were narrower and longer than those of ZH1 1 and iqd14-c plants (Fig. 1o-t and Supplemental Fig. 2c-e and 3a-i). Taken together, these results indicate that the changes in overall seed shape by modifying OsIQDI4 levels (e.g. short and wide versus long and slender) are caused by the same type of changes to the individual spikelet hull cells, and that modifying OsIQD14 transcript levels can be used as a tool to modify rice grain shape without a yield penalty under normal growth conditions. 
To understand through what mechanism OsIQD14 can alter the cell shape, we first analyzed its subcellular protein localization. Similar to some IQD protein in Arabidopsis ${ }^{10,}{ }^{11}$, p35S::OsIQD14:GFP was localized to the nucleus and cytoskeleton-related structures in rice root mersitems (Fig. 2a), Nicotiana benthamiana epidermal cells (Supplemental Fig.4a) and Arabidopsis thaliana root meristems (Fig. 2b). Considering that the cytoskeleton-associated localization was abolished by application of the MT depolymerization drug oryzalin (Fig. 2cd), OsIQD14 thus likely localizes to MT. To better understand this MT-associated localization, we used super resolution Structured Illumination Microscopy (SIM) in Arabidopsis root meristem cells. Intriguingly, we observed punctate localization of OsIQD14 along MT (Fig.2e), while structural MT proteins (p35S::GFP:TUA6 ${ }^{16}$ ) or general MT associated proteins (p35S::MAP4:GFP ${ }^{16}$ ) showed uninterrupted distribution along the filaments (Fig. 2f). This result suggests that OsIQD14 is not a generic MT binding protein, but could potentially regulate MT behavior at specific positions. Although nuclear localization of IQD proteins has been reported previously ${ }^{10}$, OsIQD14 showed strongly dynamic nuclear localization that depends on the cell cycle state (Fig. $2 b$ and Wendrich et al, submitted ${ }^{14}$ ), suggesting that IQD function during cell division is complex.

To examine whether OsIQD14 interacts with MT directly, we performed a MT spin down assay. Similar to MAP2, a generic MT-binding protein and positive control ${ }^{17}$, OsIQD14 was detected in the pellet fraction (Fig. 2g), demonstrating that OsIQD14 directly binds MT. To elucidate which part of OsIQD14 localized to MT, we generated GFP fusion proteins consisting of only the N- or C-terminal region of OsIQD14. Although both MT and nuclear localization was observed in the p35S::OsIQD14:GFP line expressing the full-length protein (Fig. 2b), the C-terminal region of OsIQD14 fused to GFP showed MT localization only, while the N-terminal region of OsIQD14 fused to GFP showed nuclear localization only (Fig. 2h-i and Supplemental Fig. 4d-i). Taken together, these results show that IQD14 binds MT directly through its C-terminal domain.

Based on the combined results described above, it is tempting to speculate that OsIQD14 controls spikelet hull cell shape by modifying the MT cytoskeleton. Unfortunately, the hardened spikelet hull cells in rice are unsuited for observing MT ordering and dynamics. However, given the identical protein localization and evolutionary conservation between AtIQD18 and OsIQD14 (Wendrich et al, submitted ${ }^{14}$ ), we transformed p35S::OsIQD14 
(OsIQD14-OE) in Arabidopsis. Similar to AtIQD16 ${ }^{10}$ and AtIQD18 (Wendrich et al, submitted $^{14}$ ) overexpression, Arabidopsis OSIQD14-OE seedlings showed narrow, long and spiraling cotyledons (Fig. 3a-b). Also, epidermal pavement cells became largely isodiametric and lost the typical jigsaw puzzle shape found in Col-0 control plants (Fig. 3c-d and Supplemental Fig. 2f-g). Indeed, MT topology was strongly affected in OsIQD14-OE plants compared to control plants as visualized by using p35S::MAP4:GFP (Fig. 3e-f). In conclusion, these results indicate that $O S I Q D 14$ overexpression in Arabidopsis alters the MT orientation. By inference, this suggests that OsIQD14 controls cell shape through affecting the MT cytoskeleton.

Intriguingly, the phenotypes observed upon OSIQD14 expression in Arabidopsis seedlings are very similar to those seen in the spiral2 mutant $^{8,18}$. SPIRAL2 (SPR2) is a plant-specific MT binding protein required for anisotropic growth in Arabidopsis ${ }^{8,18-20}$. It was shown to protect MT minus ends to promote KATANIN-dependent severing and reorientation of plant cortical microtubule arrays ${ }^{7}$. Given this striking phenotypic resemblance, we focused our attention on SPR2 in order to further understand how OsIQD14 could affect MT organization. We first tested a possible interaction between OsIQD14 and AtSPR2 using yeast two hybrid (Y2H) and bimolecular fluorescence complementation (BiFC) analyses (Fig. 3g-o). Both the in vitro $\mathrm{Y} 2 \mathrm{H}$ and the in vivo BiFC showed that OsIQD14 could interact with AtSPR2. Moreover, an interaction between the orthologous AtIQD18 and SPR2 was also recently identified (Wendrich et al, submitted ${ }^{14}$ ), strengthening these findings and suggesting that IQD-SPR2 interactions are a conserved property. Interestingly, the OsIQD14-SPR2 interaction using BiFC localized to punctuated regions on MT-like structures (Fig. 3i); suggesting IQD14 could affect MT dynamics by binding to and regulating SPR2 activity.

Although binding of Calmodulin to the IQ67 domain of IQD proteins has been reported ${ }^{10-12}$, the biological significance of this binding remains unclear. We thus tested the interaction between OsIQD14 and three rice Calmodulins, named OsCaM1, 2 and 3, all of which showed similar expression patterns to OsIQD14 in digital gene expression analysis (Supplemental Fig. 5a-c). Y2H and BiFC analyses showed that OsCaM1, 2 and 3 interact with OsIQD14 both in vitro (Fig. 4a) and in vivo at MT structures in tobacco leaf epidermal cells (Fig. 4b-g). Similar to other IQDs in Arabidopsis, IQD14 interacting with CaM1 was enhanced by calcium treatment (Fig. 4h). We next aimed to investigate the biological significance of the OsCaM1- 
OsIQD14 interaction. Introducing a p35S::OsCaM1 construct into the Arabidopsis p35S::OSIQD14 (OSIQD14-OE) plants reverted all phenotypes related to OsIQD14 overexpression back to Col-0 controls (Fig. 4i-n). These included the long, narrow and spiraling cotyledons, and the absence of jigsaw-shaped epidermal pavement cells (Fig. 4o-r). Taken together, these results strongly suggest that the $\mathrm{Ca}^{2+}$-dependent Calmodulin-OsIQD14 interaction inhibits IQD14 activity. Interestingly, the CaM-binding and MT-localization properties are separable: the CaM-interacting IQ67 domain is located in the N-terminus of OsIQD14, while the C-terminus is sufficient for MT localization (Fig. 2h). Thus, the OsIQD14 protein likely recruits CaM to MT filaments through these two binding modules.

Being the primary agronomic value trait, grain size and shape are key parameters for rice improvement. A range of regulators of grain size or shape have been identified through studying natural variation or mutagenesis ${ }^{21,22}$. Identification of causal genes has revealed the role of transcription factors (such as OsSPL16 ${ }^{23}$, OsSPL13 ${ }^{24}$, OsGRF4 ${ }^{25}$ ), a TRM-containing protein $\left(\mathrm{GW}^{23}\right)$, an auxin-metabolism protein $\left(\mathrm{TGW}^{26}\right)$, etc ${ }^{21}$. While these functions are diverse, no coherent mechanistic framework has emerged for the cellular basis underlying the altered morphology. Here, we identify the IQD14 gene as a key regulator of grain shape, acting on cell shape determination through controlling the MT cytoskeleton (Fig. 4s). Intriguingly, while mutations and overexpression consistently affect grain properties, no adverse pleiotropic effects are observed. Thus, this gene allows direct modulation of MT behavior and cell shape in husk cells to affect grain properties without the pleiotropic effects that manipulation of the MT cytoskeleton often induces ${ }^{27}$. Besides the possibility for improving a rice agronomic trait through manipulating the MT cytoskeleton without fitness penalties, we also present a mechanism that explains how multiple external and internal signals, in this case Calcium and auxin, can be integrated by OsIQD14 and translated into modifying MT ordering via SPR2. Given that similar activities and regulation were found for the Arabidopsis orthologs of OsIQD14, this module is likely deeply conserved in flowering plants. Interestingly, while molecular mechanisms are not yet resolved, altered expression of a tomato IQD gene (SUN) leads to altered fruit shape ${ }^{28}$. Thus, our study not only reveals a new mechanism for signal integration at the MT cytoskeleton, but also identifies a new role for $\mathrm{Ca}^{2+}$ in recruiting $\mathrm{CaM}$ proteins to MT and modulating the OsIQD14-SPR2 interaction. As such, our results offer novel mechanisms for organ shape modification in a wide range of crop plants. 


\section{Methods}

\section{Plant materials and growth conditions}

Rice (Oryza sativa, japonica variety Zhonghua11, ZH11) plants were cultivated in the field at Shanghai under natural growing conditions. For growth of transgenic plants, rice seeds were germinated in sterilized water and grown in a phytotron under a $12 \mathrm{~h} \mathrm{light}\left(28^{\circ} \mathrm{C}\right) / 12 \mathrm{~h}$ dark $\left(22^{\circ} \mathrm{C}\right)$ cycle. Arabidopsis thaliana ecotype Columbia-0 (Col-0) was used in all transformation and phenotype analysis. All seeds were germinated on MS (Murashige and Skoog, Duchefa) medium after three days at $4{ }^{\circ} \mathrm{C}$. Seedlings and plants were grown in a phytotron at $22^{\circ} \mathrm{C}$ with a 16-h light/8-h dark photoperiod.

\section{Vector construction and plant transformation}

The vector CRISPR/Cas9-iqd14 was generated by using two 20-bp fragments from the first exon of OsIQD14 introducing into pOsCas9 vector, and then this plasmid was transformed into rice (ZH11) by Agrobacterium tumefaciens-mediated transformation ${ }^{29}$. The IQD14 cDNA was amplified by PCR with primers IQD14-1 and IQD14-2 (Table S1) using total cDNA of ZH11 seedlings as template and subcloned into pENTR/D-TOPO (Invitrogen) to generate the pENTR/D-TOPO-IQD14 construct. For stable transformation, p35S::OsIQD14:GFP was generated by LR reactions with pGWB5 using pENTR/D-TOPO-IQD14, which was then transformed into ZH11. Expression levels of p35S::OsIQD14:GFP plants were examined by qRT-PCR and confirmed positive lines were used for further analysis.

Transformation of Arabidopsis Col-0 plants was performed by the floral-dipping procedure. Plants expressing p35S::CAM1:RFP and p35S::IQD14:GFP were generated by introducing a p35S::OsCaM1:RFP construct into p35S::OsIQD14 plants. Primers are listed in Supplementary Table S1.

\section{Promoter-reporter gene fusion studies and GUS activity analysis}

To analyze the expression pattern of IQD14 gene, a 700-bp DNA fragment of OsIQDI4 promoter was amplified by PCR using ZH11 genomic DNA as template and subcloned into pENTR/D-TOPO vector. The resultant construct pOsIQD14::GUS was generated by LR reaction with pGWB4 and transformed into $\mathrm{ZH} 11$ and confirmed positive lines were used for further analysis. GUS activity of T2 homozygous progeny of independent lines were detected 
according to previous description ${ }^{30}$ and photographed using a Nikon SMZ 800 stereoscope with a Nikon digital Coolpix 995 camera.

\section{RNA extraction and quantitative real-time PCR (qRT-PCR) analysis}

Total RNAs were extracted using Trizol reagent (Invitrogen) and reversely transcribed to firststrand cDNA. qRT-PCR analysis was performed with Real-Time PCR Master Mix (Toyobo) and data were collected using the Bio-Rad Real Time detection system in accordance with the manufacturer's instruction manual. Primers were listed in Supplementary Table S1. Expression of IQD14 was analyzed using primers IQD14-RT1 and IQD14-RT2.

\section{Scanning electron microscopy observation of spikelet hull}

Cell number and cell area in the outer parenchyma layer of the spikelet hulls were measured by Olympus stream software. The sample pretreatment for scanning electron microscopy observation (S-3000N; Hitachi) was performed as described previously ${ }^{31}$. Grain weight were analyzed as described previously ${ }^{32}$.

\section{Subcellular localization analysis}

Fluorescence of transgene seedlings and tobacco epidermal cells was observed by confocal laser scanning microscopy (Leica SP8) with an argon laser excitation wavelength of $488 \mathrm{~nm}$ or $561 \mathrm{~nm}$. For imaging with SIM, the Alpha Plan Apochromat 1003, NA 1.57 oil objective was used, and images were acquired from a single optical section.

\section{Protein-protein interaction assays}

Interaction of IQD14 and SPR2 (or CaM1) was detected by standard Y2H analysis following the manufacturer's instructions (Clontech). cDNAs encoding OsIQD14, AtSPR2, OsCaM1,2,3 were subcloned into pGBKT7 and pGADT7 vector, resulting in the fusion of IQD14-AD, SPR2-AD, CaM1-AD, IQD14-BD, SPR2-BD and CaM1-BD respectively (AD, activating domain; BD, binding domain). Primers are listed in Supplementary Table S1. Yeast transformants were spotted on the restricted SD medium (SD-Leu/-Trp, short as SD-L/T) and selective medium (SD-Leu/-Trp/-His/, short as SD-L/T/H). For BiFC (Bimolecular Fluorescence Complementation) assay, cDNAs encoding IQD14, SPR2 or CaM1 were cloned into p35S::YFP-N or p35S::YFP-C vector by gateway LR reaction, resulting in constructs expressing IQD14-cYFP, SPR2-nYFP and CaM1-nYFP, respectively. Resultant constructs with control vectors were co-expressed in $N$. benthamiana leaves and YFP was observed by 
Leica SP8 confocal microscope using an argon laser excitation wavelength of $488 \mathrm{~nm}$ after infiltration for 3 days.

\section{Recombinant expression of OsIQD14 and MT spin down assay}

Coding sequences of $O s I Q D 14$ were amplified by PCR (primers IQD14-COLD-P1/2) and subcloned into pCold-HF for expression of OsIQD14-His fusion proteins. After confirmation by sequencing, the construct was transformed into E. coli BL21(DE3) cells, and expression of the fusion protein was induced by adding isopropyl- $\beta$-D-thiogalactoside (final concentration $1 \mathrm{mM})$ at $16^{\circ} \mathrm{C}$ overnight. The cells were lysed by sonication in lysis buffer $\left(50 \mathrm{mM} \mathrm{NaH}_{2} \mathrm{PO}_{4}\right.$, $300 \mathrm{mM} \mathrm{NaCl}$ and $10 \mathrm{mM}$ imidazole, $\mathrm{pH} \mathrm{8.0)}$ and OsIQD14-His protein was purified using Ni-NTA His Bind Resin (Novagen) according to the manufacturer's protocols. In vitro MT binding assay was performed using MT binding protein spin-down assay kit (Cytoskeleton). Briefly, $5 \mu \mathrm{g}$ purified His-OsIQD14-His protein was incubated with $10 \mu \mathrm{g}$ prepolymerized bovine brain tubulin in general tubulin buffer ( $80 \mathrm{mM}$ PIPES, pH 7.0, $2 \mathrm{mM} \mathrm{MgCl}_{2}$, and 0.5 mM EGTA) containing $20 \mu \mathrm{M}$ taxol followed by centrifugation at $100,000 \mathrm{~g}$, and both soluble and pellet fractions were analyzed by SDS-PAGE and Coomassie Brilliant Blue staining.

\section{Expression of recombinant OsCaM1 and calmodulin binding assay}

Calmodulin binding assay were performed according to previous description with some modifications $^{12}$. For expression of CaM1-GST, a full-length cDNA fragment encoding the OsCaM1 were first amplified and then subcloned into pENTR/D-TOPO (Invitrogen). To express the OsCaM1-GST fusion protein, pDEST-GST were used with Gateway LR Clonase II enzyme mix (Invitrogen). The recombinant OsCaM1 protein was expressed in BL21(DE3) at $30^{\circ} \mathrm{C}$ for $4 \mathrm{~h}$ by induction with $1 \mathrm{mM}$ IPTG. Bacterial cells were harvested and sonicated in Lysis buffer (50 mM Tris-HCL, $150 \mathrm{mM} \mathrm{NaCl}$ ). After centrifugation, the supernatant was used for incubating with GST agarose. Aliquots of $100 \mu \mathrm{L}$ of CaM1-GST beads, preequilibrated with Lysis buffer, were mixed with $500 \mu \mathrm{L}$ of bacterial supernatant supplemented with $2 \mathrm{mM} \mathrm{CaCl} 2$ or $5 \mathrm{mM} \mathrm{EGTA}$ and incubated for 1 hour at $4{ }^{\circ} \mathrm{C}$ under gentle shaking. CaM1 beads were sedimented by centrifugation and washed four times with $500 \mu \mathrm{L}$ of Lysis buffer, followed by a final wash with $100 \mu \mathrm{L}$ of the same solution. The bound proteins were eluted by boiling the beads for $2 \mathrm{~min}$ in $100 \mu \mathrm{L}$ of $4 \mathrm{x}$ SDS sample buffer. Proteins of the total extract, the initial supernatant, the last wash, and the pellet fraction were analyzed by SDSPAGE and western blot using antibody against His. 
bioRxiv preprint doi: https://doi.org/10.1101/275552; this version posted March 2, 2018. The copyright holder for this preprint (which was

not certified by peer review) is the author/funder, who has granted bioRxiv a license to display the preprint in perpetuity. It is made available under aCC-BY-ND 4.0 International license.

Supplementary Table S1. Sequences of the used primers in this study. Added restriction enzymes are underlined.

\begin{tabular}{|c|c|c|c|}
\hline Constructs & Gene and application & Vector & Primers (5'-3') \\
\hline $\begin{array}{l}\text { pENTR/D-TOPO } \\
\text { IQD14 }\end{array}$ & $\begin{array}{l}\text { LOC_Os08g02250.1 } \\
\text { IQD14 CDS topo vector }\end{array}$ & pENTR/D-TOPO & $\begin{array}{l}\text { IQD14-1: caccATGGGGAAGAAGGCCGGCA } \\
\text { IQD14-2: ACGAAGCCAGCGGCGGAGGTCG }\end{array}$ \\
\hline p35S:IQD14-GFP & $\begin{array}{l}\text { For rice and Arabidopsis } \\
\text { transformation, protein location } \\
\text { and phenotype analysis }\end{array}$ & $\begin{array}{l}\text { LR reaction: } \\
\text { pGWB5+ } \\
\text { pENTR/D-TOPO } \\
\text {-IQD14 }\end{array}$ & NA \\
\hline IQD14-sgRNA & sgRNA guide IQD14 & SgRNA-rice & $\begin{array}{l}\text { IQD14-sgP1: GGCATAAGGACGACTCCCCCAACA } \\
\text { IQD14-sgP2: AAACTGTTGGGGGAGTCGTCCTTA }\end{array}$ \\
\hline P35S- Cas9-IQD14 & $\begin{array}{l}\text { For rice transformation to knock } \\
\text { out IQD14 function }\end{array}$ & $\begin{array}{l}\text { LR reaction: } \\
\text { pCas9+ } \\
I Q D 14-\operatorname{sg} R N A\end{array}$ & NA \\
\hline $\begin{array}{l}\text { pENTR/D-TOPO - } \\
\text { pIQD14 }\end{array}$ & IQD14 promoter topo vector & pENTR/D-TOPO & $\begin{array}{l}\text { pIQD14-1: caccAGAGGAATATTCCTCTCCAG } \\
\text { pIQD14-2: CAATGGCGGCCACGGGCATTG }\end{array}$ \\
\hline pIQD14-GUS & $\begin{array}{l}\text { For IQD14 promoter activity } \\
\text { analysis }\end{array}$ & $\begin{array}{l}\text { LR reaction: } \\
\text { pGWB4+pIQD14 } \\
\text {-TOPO }\end{array}$ & NA \\
\hline $\begin{array}{l}\mathrm{pENTR/D-TOPO} \mathrm{-} \\
\text { OsCaM1 }\end{array}$ & $\begin{array}{l}\text { LOC_Os03g20370, OsCaM1 } \\
\text { CDS topo vector }\end{array}$ & pENTR/D-TOPO & $\begin{array}{l}\text { CaM1-1-gata1: caccATGGCGGACCAGCTCACCGA } \\
\text { CaM1-1-gata2: CTTGGCCATCATGACCTTGA }\end{array}$ \\
\hline p35S:OsCaM1-RFP & For transformation & $\begin{array}{l}\text { LR reaction: } \\
\text { pGWB654+ } \\
\text { pENTR/D-TOPO } \\
\text {-OsCaM1 } \\
\end{array}$ & NA \\
\hline $\begin{array}{l}\text { IQD14-AD } \\
\text { IQD14-BD }\end{array}$ & For yeast two hybrid interaction & $\begin{array}{l}\text { pGBKT7 and } \\
\text { pGADT7 }\end{array}$ & $\begin{array}{l}\text { IQD14-Y2H-1: } \\
\text { GGAATTCCATATGGGGAAGAAGGCCGGCA } \\
\text { IQD14-Y2H- } \\
\text { 2:CGGGATCCACGAAGCCAGCGGCGGAGGTCG }\end{array}$ \\
\hline $\begin{array}{l}\text { CaM1-AD CaM1- } \\
\text { BD }\end{array}$ & For yeast two hybrid interaction & $\begin{array}{l}\text { pGBKT7 and } \\
\text { pGADT7 }\end{array}$ & $\begin{array}{l}\text { CaM1-Y2H-1: } \\
\text { GGAATTCCATATGGCGGACCAGCTCACCGA } \\
\text { CaM1-Y2H-2: } \\
\text { CGGGATCCCTTGGCCATCATGACCTTGA }\end{array}$ \\
\hline $\begin{array}{l}\text { SPR2-AD } \\
\text { SPR2-BD }\end{array}$ & For yeast two hybrid interaction & $\begin{array}{l}\text { pGBKT7 and } \\
\text { pGADT7 }\end{array}$ & $\begin{array}{l}\text { SPR2-Y2H1: } \\
\text { CGCCATATGAGCACACCTACAACTTCC } \\
\text { SPR2-Y2H2: } \\
\text { TccegggCTTGTCGAACTGTTGGAGATC }\end{array}$ \\
\hline IQD14-Cold & For IQD14 protein expression & pCold-HF & $\begin{array}{l}\text { IQD14-Y2H-1: } \\
\text { GGAATTCCATATGGGGAAGAAGGCCGGCA } \\
\text { IQD14-Y2H- } \\
\text { 2:CGGGATCCACGAAGCCAGCGGCGGAGGTCG }\end{array}$ \\
\hline OsCaM1-GST & $\begin{array}{l}\text { For expression of CaM1-GST } \\
\text { protein }\end{array}$ & $\begin{array}{l}\text { LR reaction: } \\
\text { pENTR/D-TOPO- } \\
\text { OsCaM1+pDEST- } \\
\text { GST } \\
\end{array}$ & NA \\
\hline $\begin{array}{l}\text { pENTR/D-TOPO } \\
\text { IQD14-C }\end{array}$ & $\begin{array}{l}\text { IQD14 C terminal CDS topo } \\
\text { vector }\end{array}$ & pENTR/D-TOPO & $\begin{array}{l}\text { IQD14-C2-1: } \\
\text { CACCATGATCGACACCGCGCGGCCCTTC } \\
\text { IQD14-C2-2: ACGAAGCCAGCGGCGGAGGTCG }\end{array}$ \\
\hline 35S-IQD14-C-GFP & $\begin{array}{l}\text { For transformation and IQD14 } \\
\mathrm{C} \text { terminal protein localization } \\
\text { analysis }\end{array}$ & $\begin{array}{l}\text { LR reaction: } \\
\text { pGWB5+ } \\
\text { pENTR/D-TOPO- } \\
\text { IQD14-C }\end{array}$ & NA \\
\hline $\begin{array}{l}\text { pENTR/D-TOPO } \\
\text { IQD14-N }\end{array}$ & $\begin{array}{l}\text { IQD14 } \mathrm{N} \text { terminal CDS topo } \\
\text { vector }\end{array}$ & pENTR/D-TOPO & $\begin{array}{l}\text { IQD14-N-1: caccATGGGGAAGAAGGCCGGCA } \\
\text { IQD14-N2: GACGCTGTAGGAGGACTTGCT }\end{array}$ \\
\hline 35S-IQD14-N-GFP & $\begin{array}{l}\text { For transformation and IQD14 } \\
\mathrm{N} \text { terminal protein localization } \\
\text { analysis }\end{array}$ & $\begin{array}{l}\text { LR reaction: } \\
\text { pGWB5+ } \\
\text { pENTR/D-TOPO- } \\
\text { IQD14-N } \\
\end{array}$ & NA \\
\hline IQD14-nYFP & BiFC assay & $\begin{array}{l}\text { LR reaction: } \\
\text { p35S:nYFP+ } \\
\text { pENTR/D-TOPO- } \\
\text { IQD14 }\end{array}$ & NA \\
\hline IQD14-cYFP & BiFC assay & $\begin{array}{l}\text { LR reaction: } \\
\text { p35S:cYFP+ } \\
\text { pENTR/D-TOPO- } \\
\text { IQD14 }\end{array}$ & NA \\
\hline OsCaM1-nYFP & BiFC assay & $\begin{array}{l}\text { LR } \quad \text { reaction: } \\
\text { p35S:nYFP+ }\end{array}$ & NA \\
\hline
\end{tabular}


bioRxiv preprint doi: https://doi.org/10.1101/275552; this version posted March 2, 2018. The copyright holder for this preprint (which was

not certified by peer review) is the author/funder, who has granted bioRxiv a license to display the preprint in perpetuity. It is made available under aCC-BY-ND 4.0 International license.

\begin{tabular}{|l|l|l|l|}
\hline & & $\begin{array}{l}\text { pENTR/D-TOPO- } \\
\text { CaM1 }\end{array}$ & \\
\hline OsCaM1-cYFP & BiFC assay & $\begin{array}{l}\text { LR reaction: } \\
\text { p35S:cYFP+ } \\
\text { pENTR/D-TOPO- } \\
\text { CaM1 }\end{array}$ & NA \\
\hline $\begin{array}{l}\text { pENTR/D-TOPO } \\
\text { SPR2 }\end{array}$ & $\begin{array}{l}\text { AT4G27060, SPR2 CDS topo } \\
\text { vector }\end{array}$ & pENTR/D-TOPO & $\begin{array}{l}\text { SPR2-TOP1:CACC ATGAGCACACCTACAACTTCC } \\
\text { SPR2-TOP2: CTTGTCGAACTGTTGGAGATC }\end{array}$ \\
\hline SPR2-nYFP & BiFC assay & $\begin{array}{l}\text { LR reaction: } \\
\text { p35S:NYFP+ } \\
\text { pENTR/D-TOPO- } \\
\text { SPR2 }\end{array}$ & NA \\
\hline SPR2-cYFP & BiFC assay & $\begin{array}{l}\text { LR reaction: } \\
\text { p35S:CYFP+ } \\
\text { pENTR/D-TOPO- } \\
\text { SPR2 }\end{array}$ & NA \\
\hline $\begin{array}{l}\text { IQD14 } \\
\text { real time PCR }\end{array}$ & Real time PCR & NA & $\begin{array}{l}\text { IQD14-RT1: ACCTTCTGGGATTCCAAGTA } \\
\text { IQD14-RT2: CTCCTGCTGGTGTCGAAC }\end{array}$ \\
\hline
\end{tabular}




\section{References}

1. Gutierrez, R., Lindeboom, J. J., Paredez, A. R., Emons, A. M. \& Ehrhardt, D. W. Arabidopsis cortical microtubules position cellulose synthase delivery to the plasma membrane and interact with cellulose synthase trafficking compartments. Nat. Cell Biol. 11, 797-806 (2009).

2. Paredez, A. R., Somerville, C. R. \& Ehrhardt, D. W. Visualization of cellulose synthase demonstrates functional association with microtubules. Science 312, 1491-1495 (2006).

3. Baskin, T. I. On the alignment of cellulose microfibrils by cortical microtubules: a review and a model. Protoplasma 215, 150-171 (2001).

4. Lindeboom, J. J. et al. A mechanism for reorientation of cortical microtubule arrays driven by microtubule severing. Science 342, 1245533 (2013).

5. Nick, P., Bergfeld, R., Schafer, E. \& Schopfer, P. Unilateral reorientation of microtubules at the outer epidermal wall during phototropic and gravitropic curvature of maize coleoptiles and sunflower hypocotyls. Planta 181, 162-168 (1990).

6. Bergfeld, R., Speth, V. \& Schopfer, P. Reorientation of microfibrils and microtubules at the outer epidermal wall of maize coleoptiles during auxin-mediated growth. Bot. Acta. 101, 5767 (1988).

7. Nakamura, M., Lindeboom, J. J., Saltini, M., Mulder, B. M. \& Ehrhardt, D. W. SPR2 protects minus ends to promote severing and reorientation of plant cortical microtubule arrays. J. Cell Biol. doi:10.1083/jcb.201708130 (2018).

8. Wightman, R., Chomicki, G., Kumar, M., Carr, P. \& Turner, S. R. SPIRAL2 determines plant microtubule organization by modulating microtubule severing. Curr. Biol. 23, 19021907 (2013).

9. Abel, S., Savchenko, T. \& Levy, M. Genome-wide comparative analysis of the IQD gene families in Arabidopsis thaliana and Oryza sativa. BMC Evol. Biol. 5, 72 (2005).

10. Burstenbinder, K. et al. The IQD family of calmodulin-binding proteins links calcium signaling to microtubules, membrane subdomains, and the nucleus. Plant Physiol. 173, 16921708 (2017).

11. Burstenbinder, K. et al. Arabidopsis Calmodulin-binding protein IQ67-domain 1 localizes to microtubules and interacts with kinesin light chain-related protein-1. J. Biol. Chem. 288, 1871-1882 (2013).

12. Levy, M., Wang, Q., Kaspi, R., Parrella, M. P. \& Abel, S. Arabidopsis IQD1, a novel calmodulin-binding nuclear protein, stimulates glucosinolate accumulation and plant defense. Plant J. 43, 79-96 (2005).

13. Moller, B. K. et al. Auxin response cell-autonomously controls ground tissue initiation in the early Arabidopsis embryo. Proc. Natl Acad. Sci. USA 114, 2533-2539 (2017).

14. Wendrich, J.R. et al. IQD proteins integrate auxin and calcium signaling to regulate microtubule dynamics during Arabidopsis development. submitted B2B. 
15. Miao, J. et al. Targeted mutagenesis in rice using CRISPR-Cas system. Cell Res. 23, 1233 1236 (2013).

16. Mei, Y., Gao, H. B., Yuan, M. \& Xue, H. W. The Arabidopsis ARCP protein, CSI1, which is required for microtubule stability, is necessary for root and anther development. Plant Cell 24, 1066-1080 (2012).

17. Lewis, S. A., Wang, D. H. \& Cowan, N. J. Microtubule-associated protein MAP2 shares a microtubule binding motif with tau protein. Science 242, 936-939 (1988).

18. Shoji, T. et al. Plant-specific microtubule-associated protein SPIRAL2 is required for anisotropic growth in Arabidopsis. Plant Physiol. 137, 1169-1169 (2005).

19. Yao, M., Wakamatsu, Y., Itoh, T. J., Shoji, T. \& Hashimoto, T. Arabidopsis SPIRAL2 promotes uninterrupted microtubule growth by suppressing the pause state of microtubule dynamics. J. Cell. Sci. 121, 2372-2381 (2008).

20. Shoji, T. et al. Plant-specific microtubule-associated protein SPIRAL2 is required for anisotropic growth in arabidopsis. Plant Physiol. 136, 3933-3944 (2004).

21. Li, N. \& Li, Y. Signaling pathways of seed size control in plants. Curr. Opin. Plant Biol. 33, 23-32 (2016).

22. Zheng, J., Zhang, Y. D. \& Wang, C. L. Molecular functions of genes related to grain shape in rice. Breeding Sci. 65, 120-126 (2015).

23. Wang, S. et al. The OsSPL16-GW7 regulatory module determines grain shape and simultaneously improves rice yield and grain quality. Nat. Genet. 47, 949-954 (2015).

24. Si, L. Z. et al. OsSPL13 controls grain size in cultivated rice. Nat. Genet. 48, 447-456 (2016).

25. Hu, J. et al. A rare allele of GS2 enhances grain size and grain yield in rice. Mol. Plant $\mathbf{8}$, 1455-1465 (2015).

26. Ishimaru, K. et al. Loss of function of the IAA-glucose hydrolase gene TGW6 enhances rice grain weight and increases yield. Nat. Genet. 45, 707-711 (2013).

27. Hashimoto, T. Microtubules in plants. Arabidopsis Book 13, (2015).

28. Xiao, H., Jiang, N., Schaffner, E., Stockinger, E. J. \& van der Knaap, E. A retrotransposonmediated gene duplication underlies morphological variation of tomato fruit. Science 319, 1527-1530 (2008).

29. Hiei, Y., Ohta, S., Komari, T. \& Kumashiro, T. Efficient transformation of rice (Oryza sativa L.) mediated by Agrobacterium and sequence analysis of the boundaries of the T-DNA. Plant J. 6, 271-282 (1994).

30. Jefferson, R. A., Kavanagh, T. A. \& Bevan, M. W. Gus fusions - beta-glucuronidase as a sensitive and versatile gene fusion marker in higher-plants. EMBO J. 6, 3901-3907 (1987).

31. Liu, L. C. et al. Activation of Big Grain1 significantly improves grain size by regulating auxin transport in rice. Proc. Natl Acad. Sci. USA 112, 11102-11107 (2015). 
32. Fu, F. F. \& Xue, H. W. Coexpression analysis identifies rice starch regulator1, a rice AP2/EREBP family transcription factor, as a novel rice starch biosynthesis regulator. Plant Physiol. 154, 927-938 (2010).

\section{Acknowledgements}

Funding for this research is gratefully acknowledged from the National Transformation Science and Technology Program (2016ZX08001006-009), The National Key Research and Development Program of China (2016YFD0100501, 2016YFD0100902) and the National Natural Science Foundation of China (31671660). B.D.R. was funded by The Research Foundation - Flanders (FWO; Odysseus II G0D0515N and 12D1815N) and Netherlands Organization for Scientific Research (NWO; VIDI 864.13.00). We thank Ms. Shu-Ping Xu (SIPPE) for assisting with the rice transformation.

\section{Author contributions}

H.X. and D.W. conceived the project; B.Y. and J.R.W. designed experiments; B.Y. performed experiments; H.X. and D.W. supervised the project; B.Y., B.D.R., D.W. and H.X. wrote the paper with input from all authors.

\section{Competing interests}

The authors declare no competing financial interests. 


\section{Figure legends}

\section{Figure 1 | OsIQD14 regulates rice seed size and hull cell shape}

a-c, Promoter-GUS fusion studies showed the OsIQD14 expression in young panicle $(0.4 \mathrm{~cm})$ and lemma before anthesis of rice. Representative images are shown. Bar=2mm. d, qRT-PCR analysis revealed the up-regulated expression of OsIQDI4 under short time (30min-420 min) auxin treatment (10 $\mu \mathrm{M}$ IAA). Rice seedling roots were used and expressions were normalized with the ACTIN transcript and relative expression levels were calculated by setting the OsIQD14 expression in the absence of auxin as "1.0". Experiments were biological repeated and data are shown as mean \pm standard error (SE). e-j, Grain morphology of ZH11 and rice transgenic plants deficiency of (iqd14-C) or overexpressing (p35S::IQD14 or IQD14-OE) OsIQD14. Bar=20 mm. k-m, Measurement and statistical analysis of seed length and width (k), length/width ratio (1), and thousand-grain-weight (m) of ZH11, iqd14-C and IQD14-OE plants. data are shown as mean $\pm \mathrm{SE}(\mathrm{n}>300)$. $\mathbf{n}$, Harvested panicles of one plant individual in ZH11, iqd14-C and OsIQD14-OE plants. Scale bar=2 cm. o-t, Scanning electron microscopy observation of seeds with hulls and outer glume (r-t, bar=100 $\mu \mathrm{m})$ of the lemma among ZH11, iqd14-C and IQD14-OE plants. Bar=1 mm.

\section{Figure 2 | OsIQD14 protein is located at microtubules and in the nucleus}

a, Subcellular localization of 35S::OsIQD14:GFP in rice root meristem region. Bar $=10 \mu \mathrm{m}$. $\mathbf{b}$, Subcellular localization of 35S::OsIQD14:GFP in Arabidopsis root meristem region (Bar = $10 \mu \mathrm{m})$. c-d, Super resolution structured illumination microscopy (SIM) analysis of 35S::OsIQD14:GFP and p35S::MAP4:GFP localization at microtubules in Arabidopsis thaliana root epidermis cells at meristem region $(\operatorname{Bar}=5 \mu \mathrm{m})(\mathbf{c})$ and $10 \mu \mathrm{m}(\mathbf{d})$. e-f, IQD14 protein is localized to microtubules (e) and is depolymerized by $50 \mu \mathrm{M}$ oryzalin treatment for 1.5 hour $(\mathbf{f})$ in Nicotiana benthamiana epidermis cells $($ Bar $=5 \mu \mathrm{m})$. g. In vitro microtubule spin down assay showed that OsIQD14 binds to microtubules directly. IQD14-His protein was incubated without or with taxol-stabilized bovine MT $(20 \mu \mathrm{M})$, divided into pellet and soluble (Supernatant) fractions by ultracentrifugation, and then separated by 4-12\% SDS-PAGE and stained with Coomassie brilliant blue. MAP2: positive control protein $(280 \mathrm{kD})$, which bind to microtubules. BSA: negative control protein. $68 \mathrm{kD}$. h-i, Root cells of 7 days old transgenic Arabidopsis seedlings expression C terminal of IQD14-GFP $(\mathbf{h}, \mathrm{Bar}=5 \mu \mathrm{m})$ or $\mathrm{N}$ terminal of IQD14-GFP (i, Bar $=20 \mu \mathrm{m})$, which localized to microtubules or nucleus, respectively. 
Figure 3 | OsIQD14 regulates the shape of Arabidopsis pavement cells by affecting microtubule ordering

a-b, Phenotype of wild type (Col-0) and p35S::OsIQD14 in Arabidopsis (Bar = 0.5cm). c-d, Epidermal pavement cell phenotype of Col-0 and p35S::OsIQD14 (Bar $=25 \mu \mathrm{m})$. e-f, Microtubule ordering in $\mathrm{p} 35 \mathrm{~S}:: M A P 4: \mathrm{GFP}$ and 35S::OsIQD14:GFP pavement cells $(\mathrm{Bar}=20$ $\mu \mathrm{m})$. g, Yeast-2-hybrid assay showed that OsIQD14 interacts with SPR2 directly in vitro. Fulllength cDNAs of OsIQD14, SPR2 were subcloned into pGBKT7 and pGADT7 vectors and yeast cells were grown on synthetic dropout (SD-2: -Trp, -Leu; SD-3: -Trp, -His, -Leu) medium. Empty pGADT7 or pGBKT7 vectors transformed with OsIQD14-BD and SPR2-AD were used as negative controls. $\mathrm{AD}$, activating domain; $\mathrm{BD}$, binding domain. h-o, BiFC assay showed that the OsIQD14 interact with SPR2 at microtubule in Nicotiana benthamiana

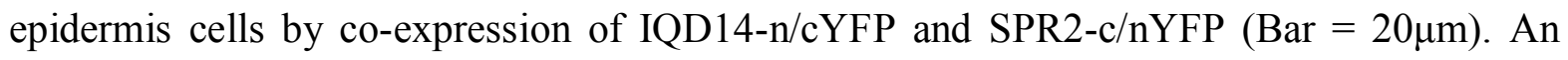
enlarged view was showed as $\mathbf{i}$ and $\mathbf{k}(\mathrm{Bar}=10 \mu \mathrm{m})$. Empty $\mathrm{n} / \mathrm{c}$ YPF was used as negative controls (i-o).

\section{Figure 4 | Calmodulins inhibit OsIQD14 activity}

a, Yeast-2-hybrid assay showed that IQD14 interacts with OsCaM1, 2 and 3 directly in vitro. Full-length cDNAs of OsIQD14, OsCaM1/2/3 were subcloned into pGBKT7 or pGADT7 vectors and yeast cells were grown on synthetic dropout (SD-2: -Trp, -Leu; SD-3: -Trp, -His, -Leu) medium. Empty pGADT7 or pGBKT7 vectors transformed with OsIQD14-BD and OsCaM1/2/3-AD were used as negative controls. $\mathrm{AD}$, activating domain; $\mathrm{BD}$, binding domain. b-g, BiFC assay showed that OsIQD14 interacts with OsCaM1 at microtubules in Nicotiana benthamiana epidermis cells by co-expression of IQD14-n/cYFP and CaM1-c/nYFP, (Bar = $20 \mu \mathrm{m}$ ). $\mathbf{c}$ and $\mathbf{f}$ showed an enlarged view of interaction zone closed to plasma membrane (Bar $=5 \mu \mathrm{m})$. Empty $\mathrm{n} / \mathrm{c}$ YPF was used as negative controls (d and $\mathbf{g}$ ). $\mathbf{h}$, Calcium dependent OsCaM1-OsIQD14 in vitro. GST beads loaded with GST-tagged Calmodulin (CaM1) were incubated with IQD14-His protein at $4^{\circ} \mathrm{C}$ in the presence of $2 \mathrm{mM} \mathrm{CaCl}_{2}$ or $5 \mathrm{mM}$ EGTA. Pellet (GST-OsCaM1 beads) fraction was detected by probing with His antibody (top) or stained with Coomassie brilliant blue (bottom). i-n, Cotyledon phenotype of the indicated genotypes $(\mathrm{Bar}=1 \mathrm{~cm})$. o-r, Epidermal pavement cell phenotype of the indicated genotypes. PI was used to stain cell wall $(\mathrm{Bar}=50 \mu \mathrm{m})$. f, A proposed model for Calmodulin-IQD14SPR2 in regulating microtubule ordering in rice hull cells and seed size. 


\section{Supplemental Figure legends}

\section{Supplementary Figure 1 | Expression pattern of $O$ sIQD14 and $O$ sARF11 in rice tissues}

a, OsIQD14 digital expression levels in leaf, root, inflorescence, anther, pistil, lemma, palea, embryo and endosperm. b, OsIQD14 digital expression levels in different stage of inflorescence, anther, pistil, lemma and palea. c, Quantitative RT-PCR (qRT-PCR) analysis revealed the transcription of OSIQD14 in various tissues including SAM, leaf, and young panicles (YP) at different developmental stages (indicated as the lengths of panicles, $\mathrm{cm}$ ). The expressions were normalized with the ACTIN transcript and relative expression levels were calculated by setting the OSIQD14 expression in Leaf as "1.0". Experiments were biological repeated and data are shown as mean \pm standard error (SE). d, Quantitative RT-PCR (qRTPCR) analysis revealed the transcription of $O S A R F 11(M P)$ in various tissues including SAM, leaf, and young panicles (YP) at different developmental stages (indicated as the lengths of panicles, cm). The expressions were normalized with the ACTIN transcript and relative expression levels were calculated by setting the OSARF11(MP) expression in Leaf as "1.0". Experiments were biological repeated and data are shown as mean \pm standard error (SE).

\section{Supplementary Figure 2 | Additional OsIQD14 loss- and gain-of-function phenotypes}

a, Targeted mutagenesis of IQDI4 gene. The position of target site is shown on the gene sequence. The spacer sequence is shaded in black. Sequencing results of mutant alleles are aligned to the reference genome sequence. $\mathbf{b}$, Seed phenotype of different mutagenesis of IQD14 $($ Bar $=1 \mathrm{~cm}) . \mathbf{c}-\mathbf{e}$, Scanning electron microscopy observation of seeds without hulls among ZH11 (c), iqd14-C (d)and p35S::OsIQD14 (e) plants (Bar = 1mm). f-g, Cotyledon phenotype of Col-0 (f) and p35S::OsIQD14 plants $(\mathbf{g})(\mathrm{Bar}=1.5 \mathrm{~mm})$.

\section{Supplementary Figure 3 | Effect of modulating OsIQD14 expression levels on spikelet hull cells}

a-i, Cross-sections of the spikelet hulls of WT (a-c), iqd14-c (d-f) and p35S::OsIQD14 (g-i) $($ bar $=1 \mathrm{~mm})$. Magnified views of the left column are shown in the middle and right columns $(\operatorname{Bar}=0.1 \mathrm{~mm})$. 
bioRxiv preprint doi: https://doi.org/10.1101/275552; this version posted March 2, 2018. The copyright holder for this preprint (which was

not certified by peer review) is the author/funder, who has granted bioRxiv a license to display the preprint in perpetuity. It is made available under aCC-BY-ND 4.0 International license.

\section{Supplementary Figure 4 | Protein localization of OsIQD14}

a, Subcellular localization of 35S::OsIQD14:GFP in N. benthamiana leaf epidermis cells (Zstack projection; Bar $=20 \mu \mathrm{m})$. b-c, $35 \mathrm{~S}:: O s I Q D 14: \mathrm{GFP}$ is localized to microtubules (left) and depolymerized by oryzalin treatment in Arabidopsis root cells $(\mathrm{Bar}=5 \mu \mathrm{m})$. d-f, The Nterminal region of OsIQD14 fused to GFP is localized to the nucleus (Bar $=20 \mu \mathrm{m})$ in $N$. benthamiana epidermis cells. g-i, The C-terminal region of OsIQD14 fused to GFP is localized to microtubules $(\mathrm{Bar}=20 \mu \mathrm{m})$. $\mathbf{e}, \mathbf{f}$ and $\mathbf{h}, \mathbf{i}$ show the enlarged zone close to plasma membrane and nucleus (Bar $=10 \mu \mathrm{m}$ or $5 \mu \mathrm{m}$ respectively).

\section{Supplementary Figure 5 | Expression pattern of $O s C a M 1,2$ and 3 in rice tissue}

a-c, $O s C a M 1,2$ and 3 digital expression levels in leaf, root, inflorescence, anther, pistil, lemma, palea, embryo and endosperm tissues of rice. 


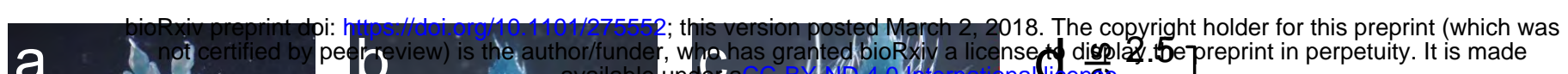
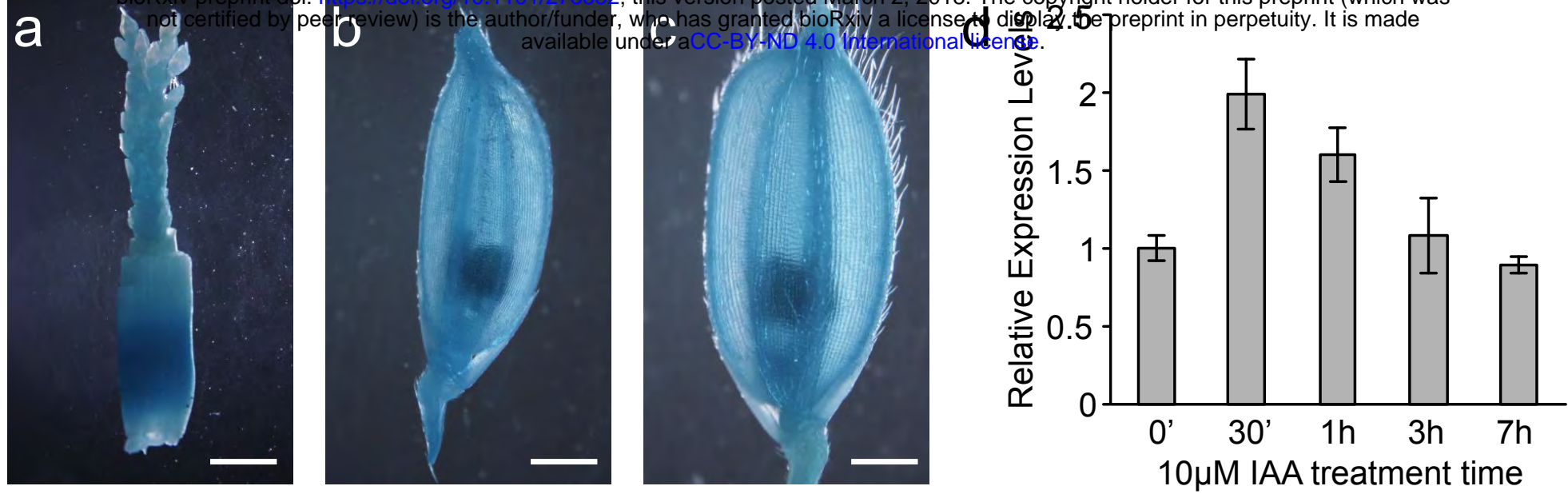

e

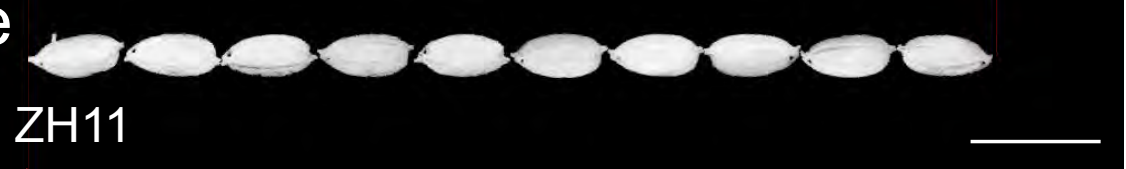

f
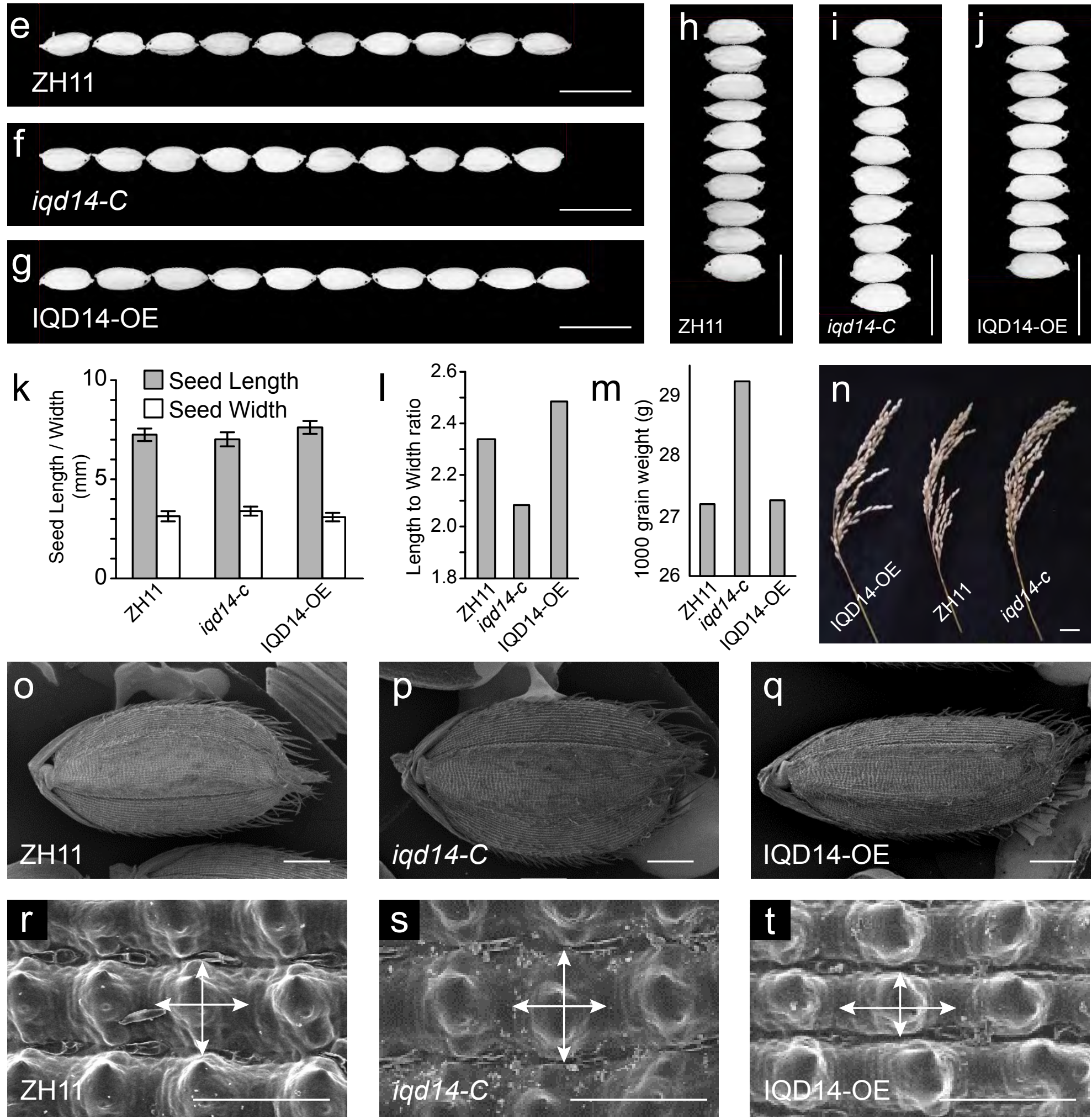

Figure 1 
bioRxiv preprint doi: https://doi.org/10.1101/275552; this version posted March 2, 2018. The copyright holder for this preprint (which was

not certified by peer review) is the author/funder, who has granted bioRxiv a license to display the preprint in perpetuity. It is made

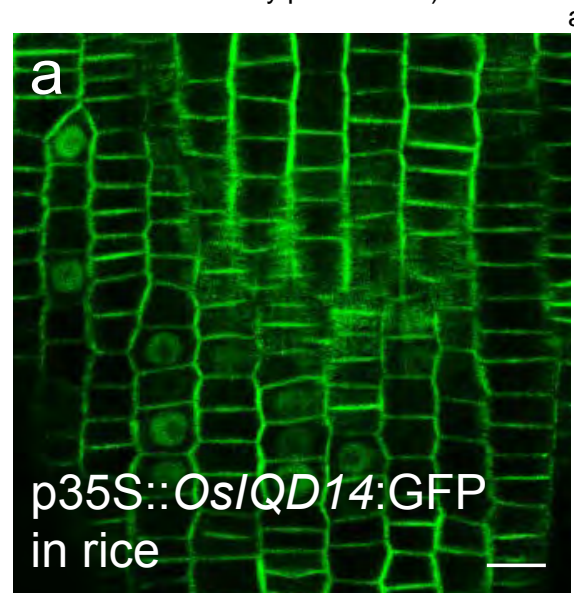
available under aCC-BY-ND 4.0 International license.
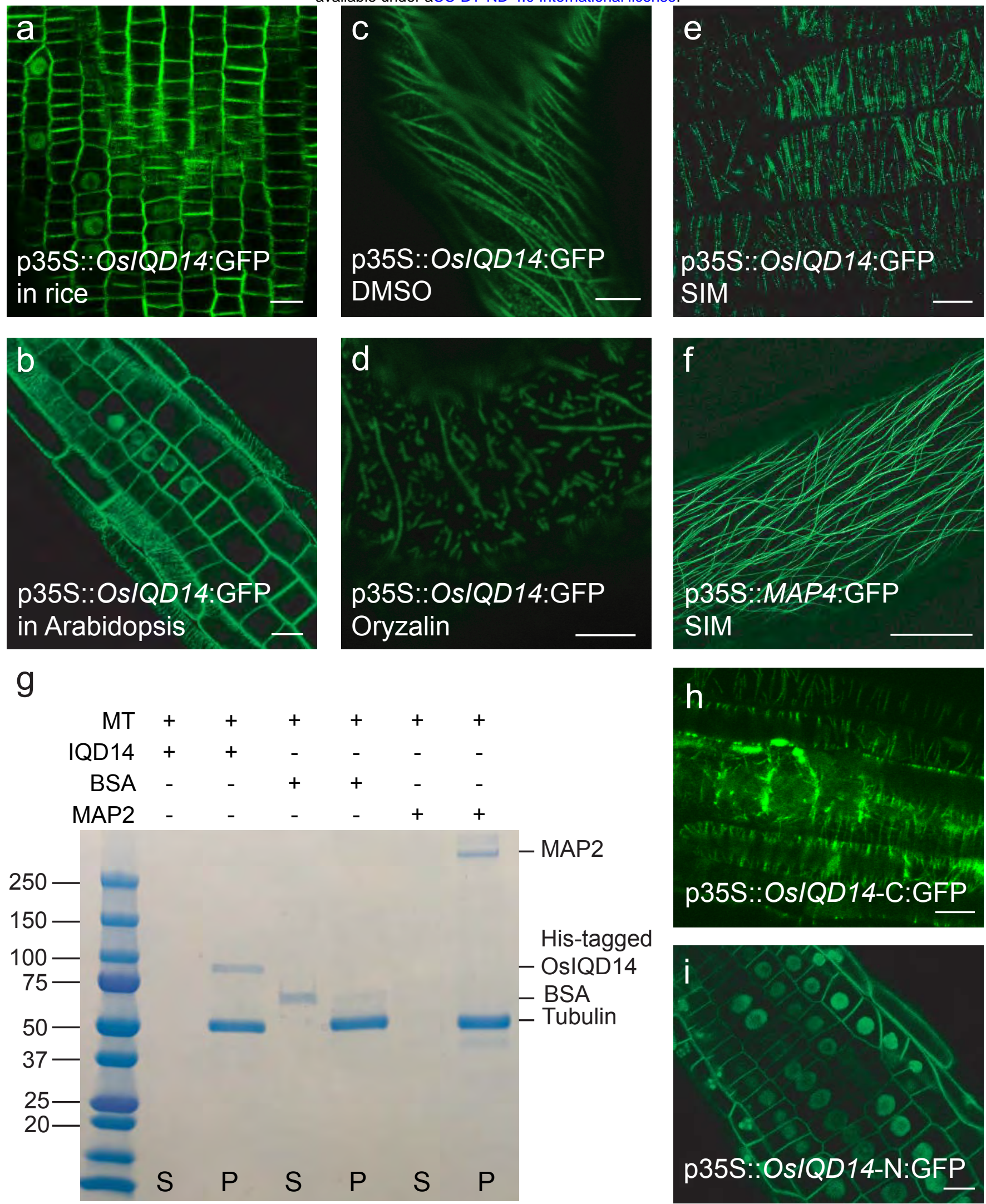

Figure 2 
bioRxiv preprint doi: https://doi.org/10.1101/275552; this version posted March 2, 2018. The copyright holder for this preprint (which was

not certified by peer review) is the author/funder, who has granted bioRxiv a license to display the preprint in perpetuity. It is made available under aCC-BY-ND 4.0 International license.
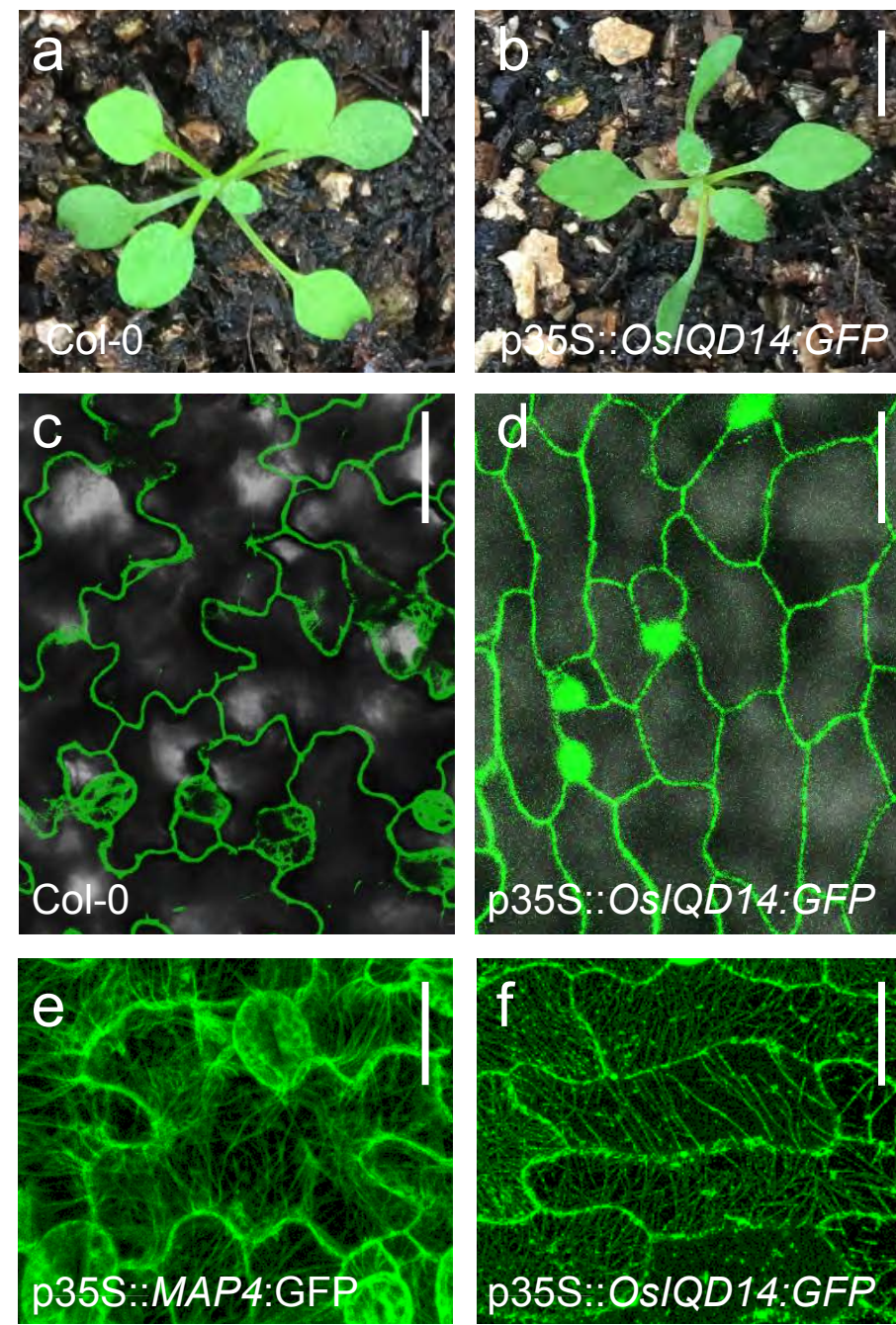

g

$$
\begin{gathered}
\text { AtSPR2-AD + BD } \\
\text { AD + OsIQD14-BD } \\
\text { AtSPR2-AD + } \\
\text { OsIQD14-BD }
\end{gathered}
$$
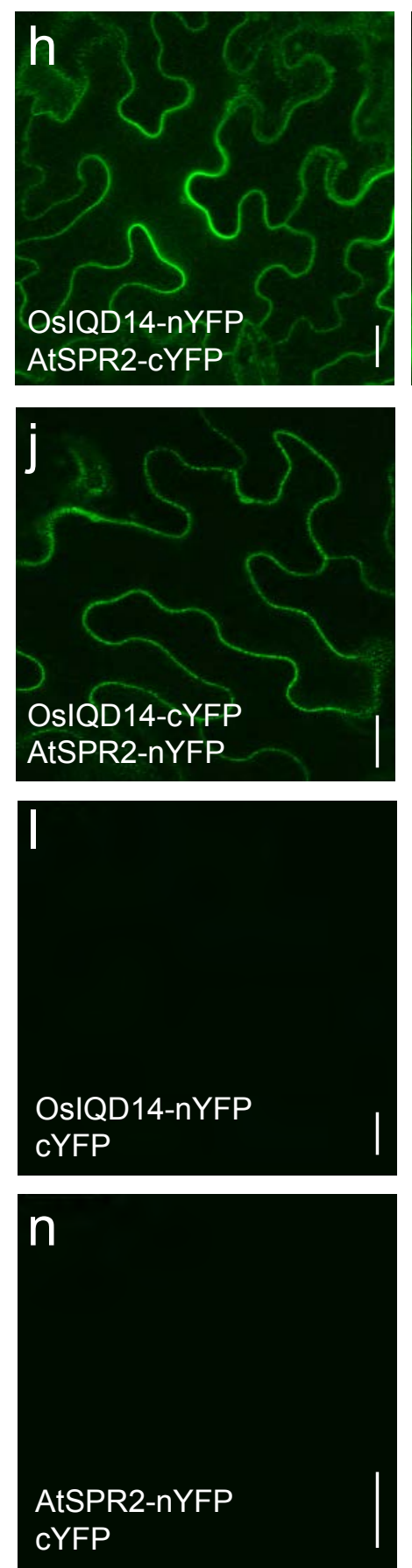
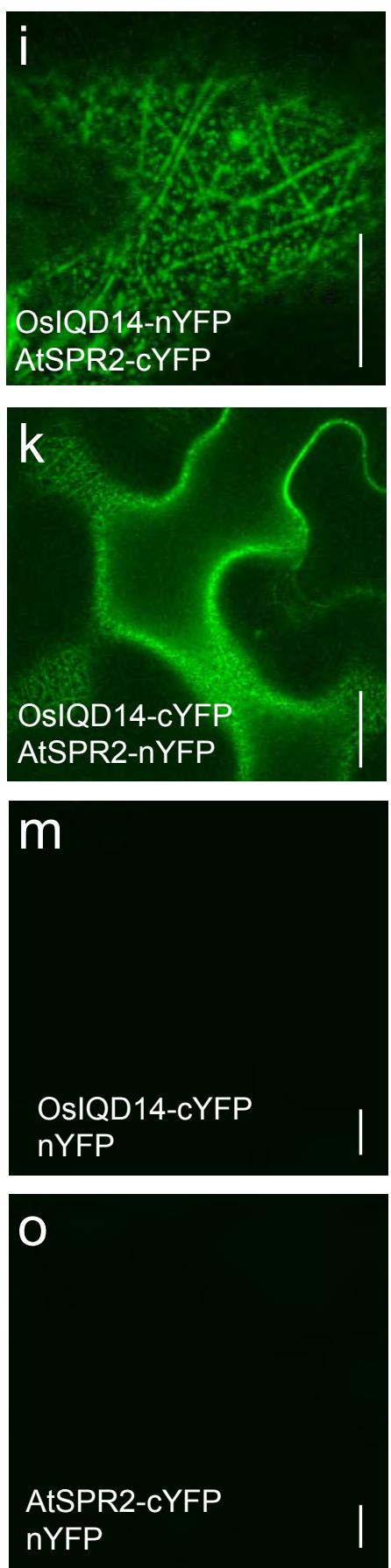

Figure 3 
bioRxiv preprint doi: https://doi.org/10.1101/275552; this version posted March 2, 2018. The copyright holder for this preprint (which was

not certified by peer review) is the author/funder, who has granted bioRxiv a license to display the preprint in perpetuity. It is made
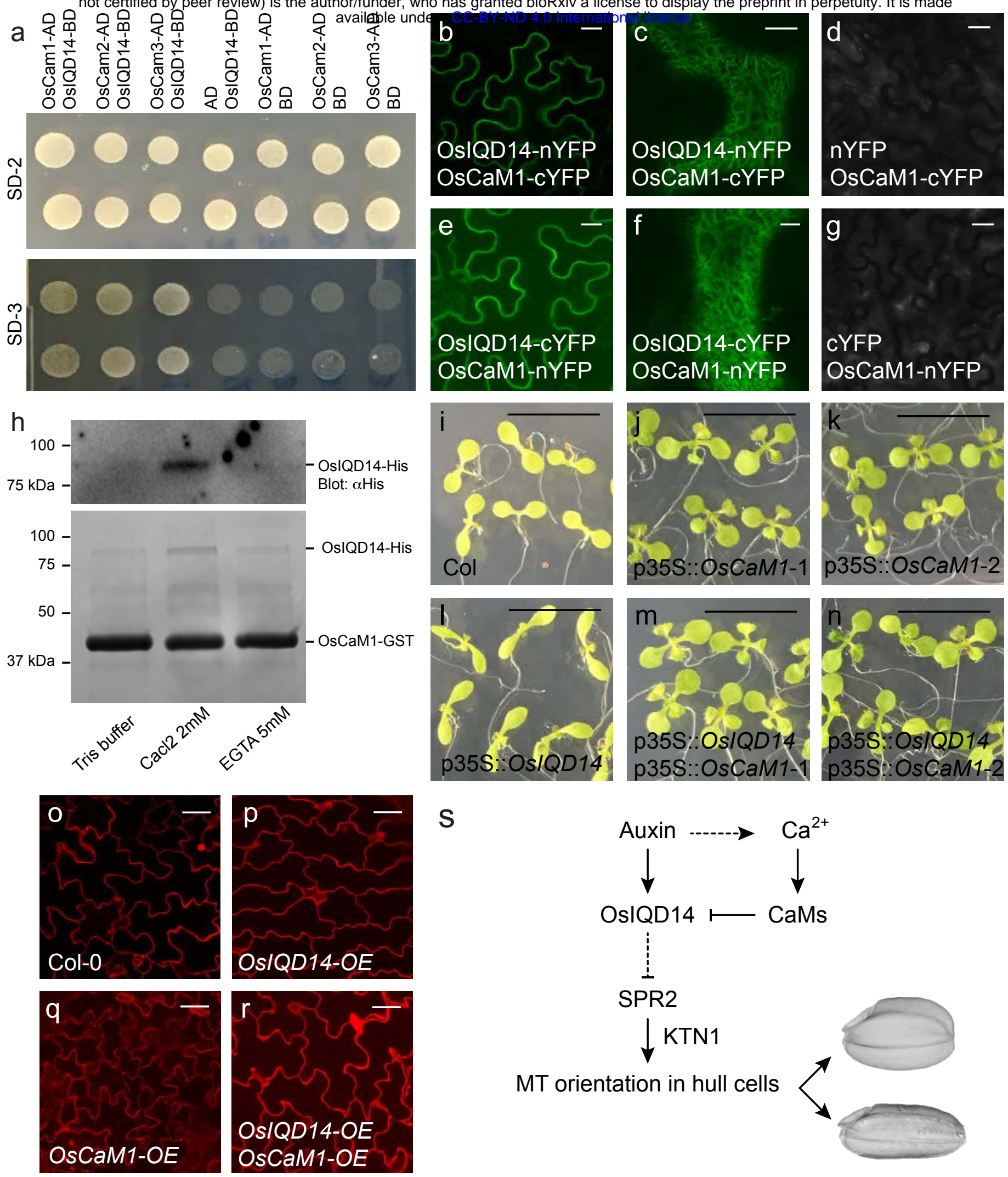

S
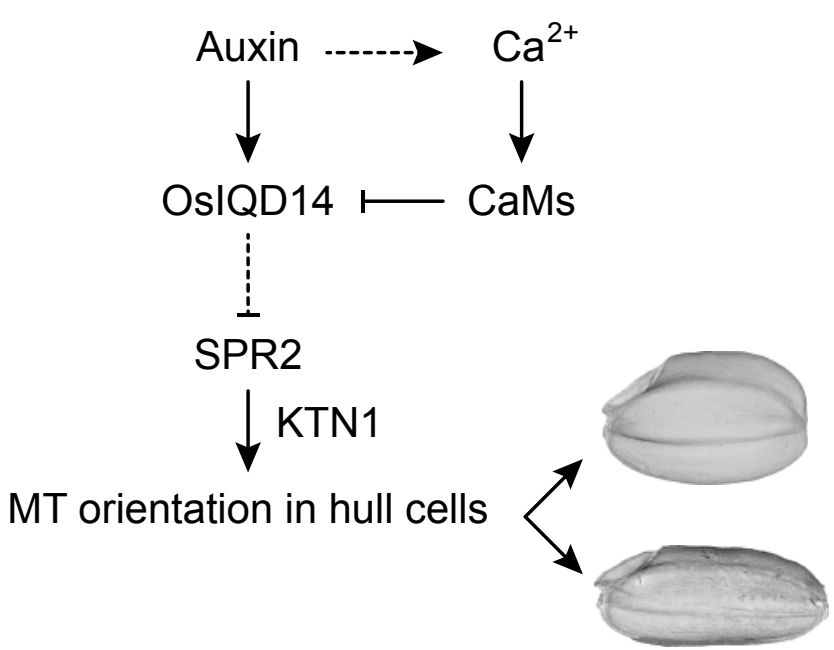

Figure 4 

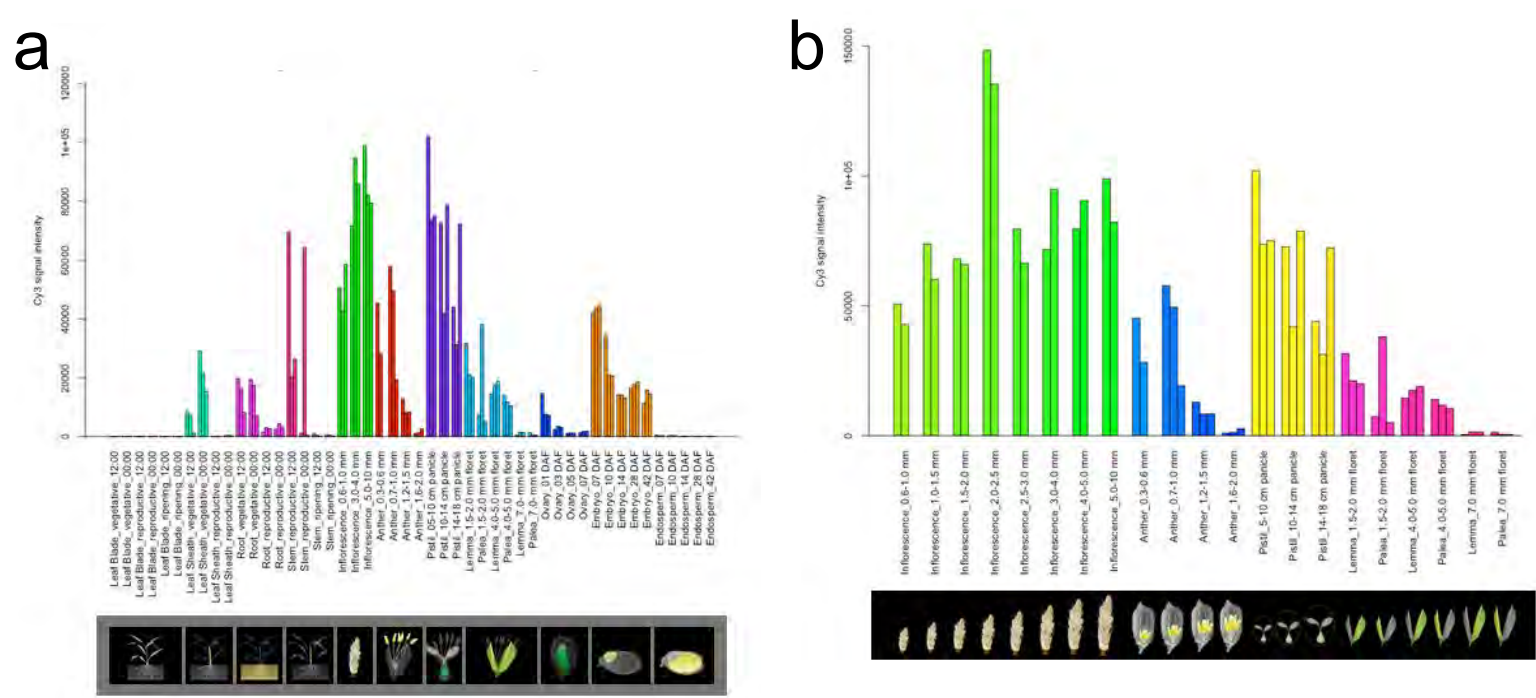

1111010000maruvevev
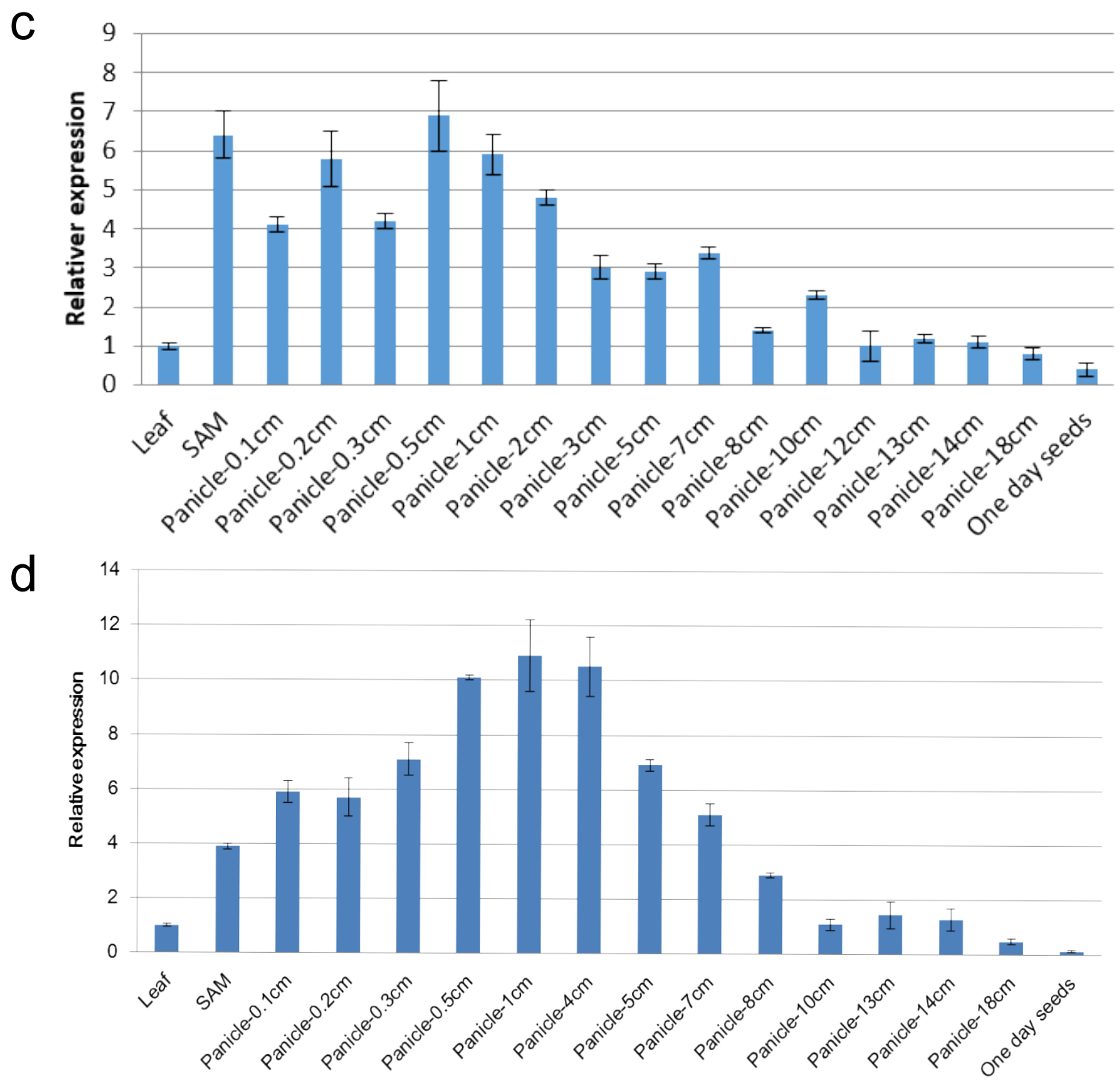

Supplemental Figure 1 
bioRxiv preprint doi: https://doi.org/10.1101/275552; this version posted March 2, 2018. The copyright holder for this preprint (which was not certified by peer review) is the author/funder, who has granted bioRxiv a license to display the preprint in perpetuity. It is made available under aCC-BY-ND 4.0 International license.

a

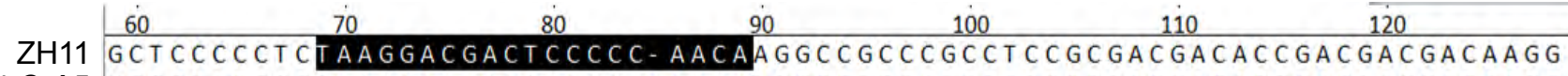
iqd14-C-A5 GCTCCCCCTCTAAGGACGACTCCCCCAAACAAGCCGCCCGCCTCCGCGACGACACCGACGACGACAAGG iqd14-C-F2 GCTCCCCCTCTAAGGACGACTCC.... AACAAGGCCGCCCGCCTCCGCGACGACACCGACGACGACAAGG iqd14-C-D7 GCTCCCCCTCTAAGGACGACTC...... ACAAGGCCGCCCGCCT CCGCGACGACACCGACGACGACAAGG

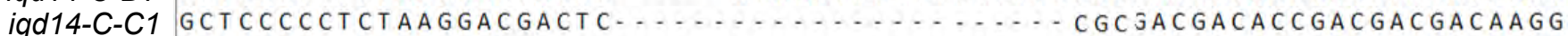

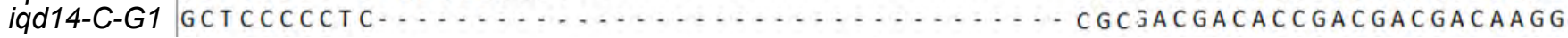
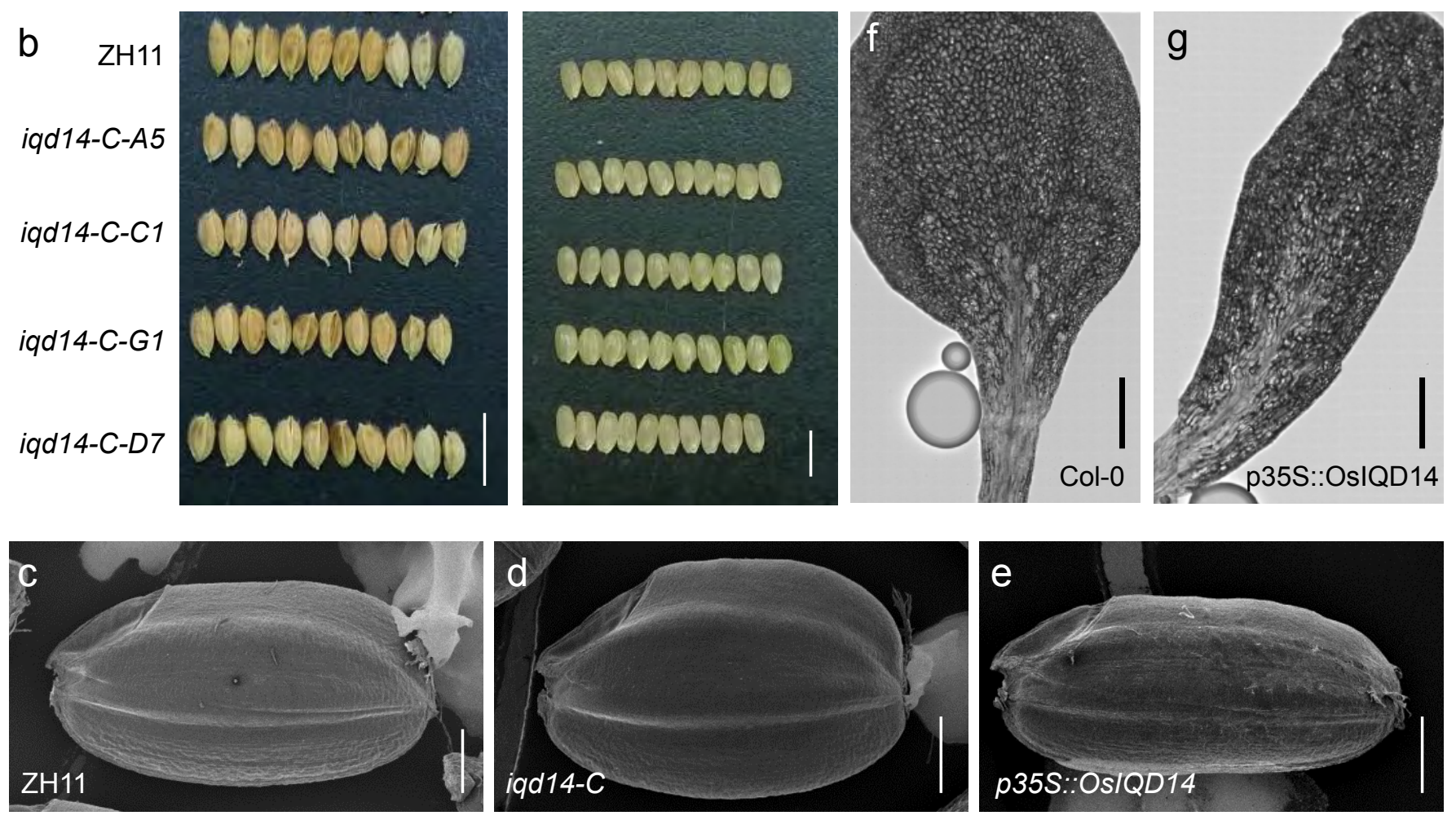

Supplemental Figure 2 

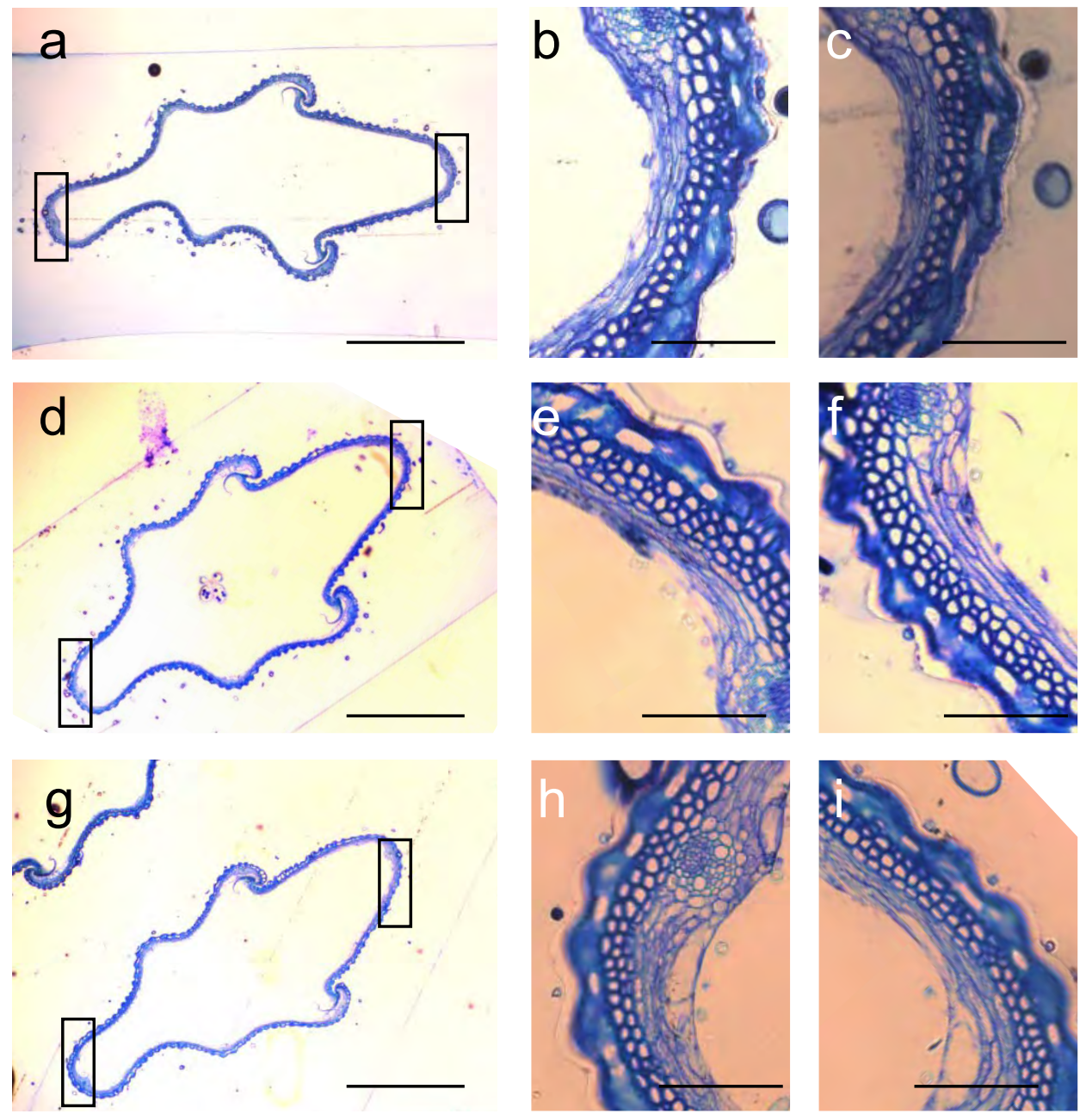

Supplemental Figure 3 
bioRxiv preprint doi: https://doi.org/10.1101/275552; this version posted March 2, 2018. The copyright holder for this preprint (which was

not certified by peer review) is the author/funder, who has granted bioRxiv a license to display the preprint in perpetuity. It is made
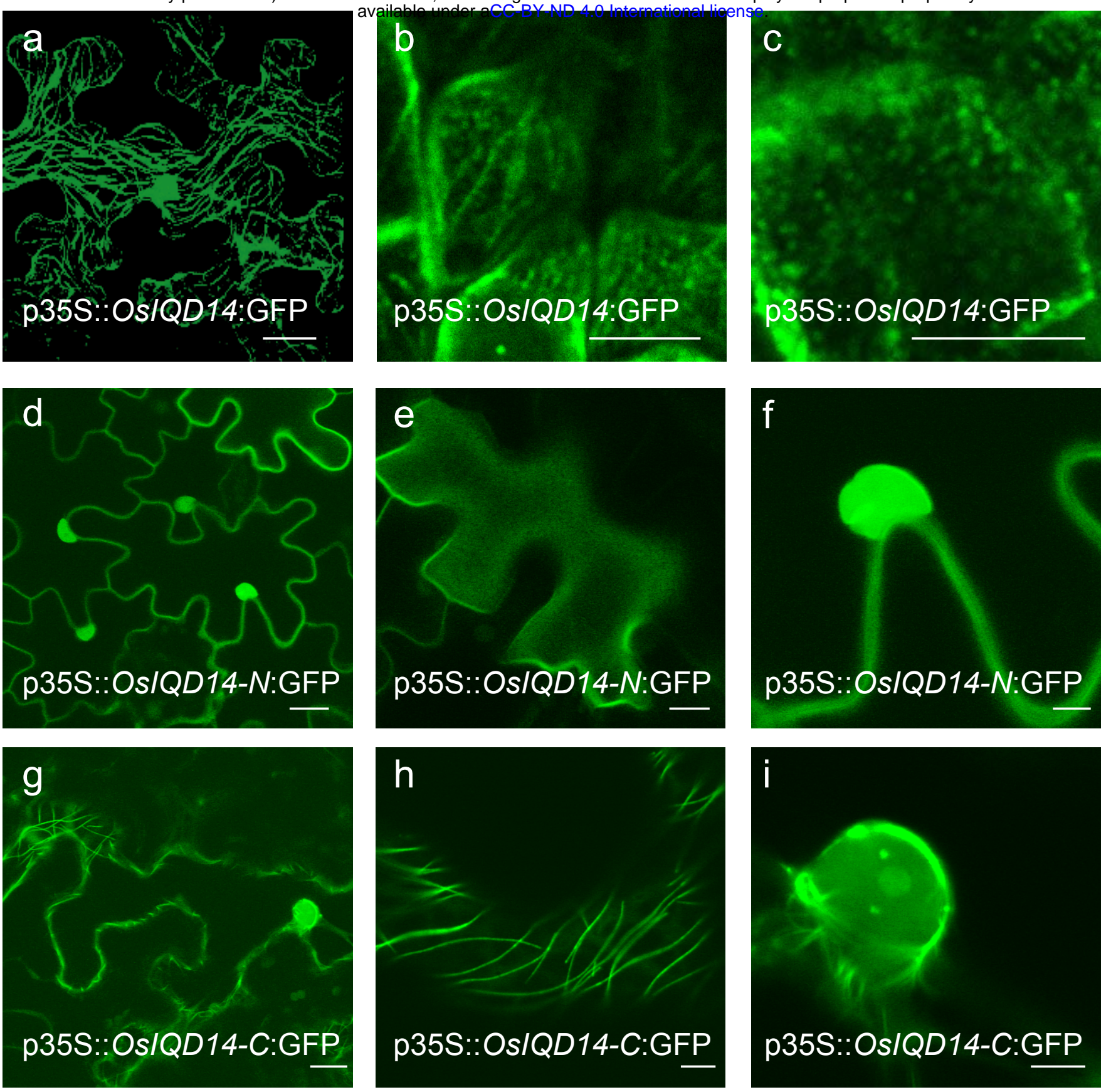

Supplemental Figure 4 
bioRxiv preprint doi: https://doi.org/10.1101/275552; this version posted March 2, 2018. The copyright holder for this preprint (which was

not certified by peer review) is the author/funder, who has granted bioRxiv a license to display the preprint in perpetuity. It is made available under aCC-BY-ND 4.0 International license.

a

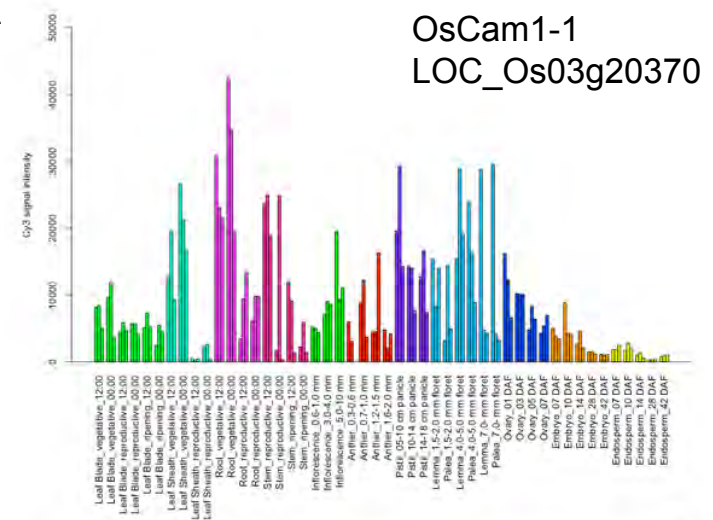

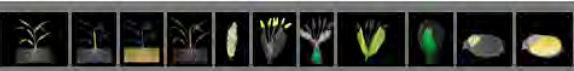

b
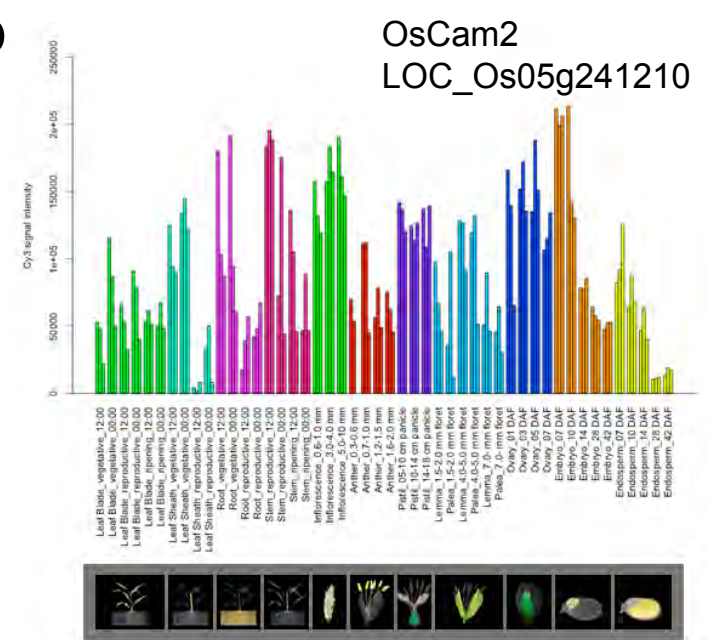

C

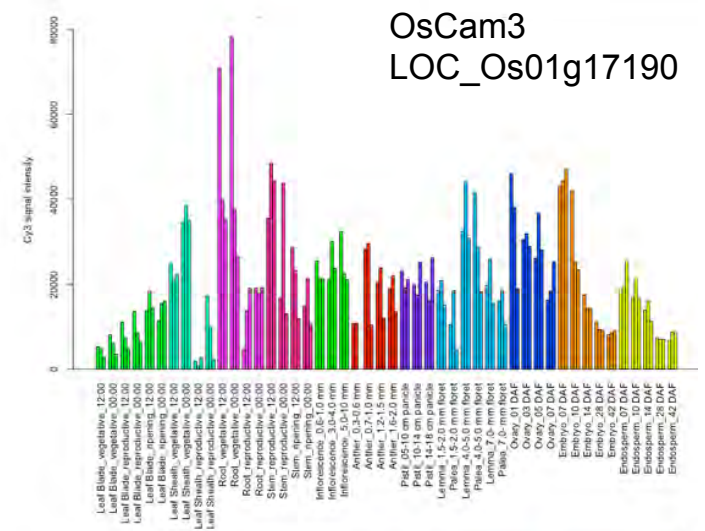

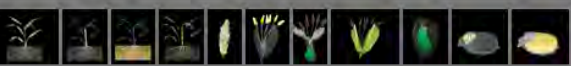

